\title{
Televisão, o futuro será: a consolidação de uma cultura televisa visualizada nas performances midiáticas e juvenis dos anos de $1980^{1}$
}

\author{
Televisión, el futuro será: laconsolidación de una cultura televisiva \\ visualizada enlas performances mediáticas y juveniles de losaños de \\ la década de 1980
}

\section{Television, the future will be: the consolidation of a television culture displayed in media and youth performances $1980 \mathrm{~s}$}

\author{
Marina Caminha ${ }^{2}$
}

\begin{abstract}
Resumo:
Palavras chave:

Esse artigo tem como proposta por em perspectiva as disputas memoráveis visualizadas nas práticas juvenis de 1980 para apresentar

Televisão um olhar sobre a maneira como a televisão tornou-se uma instância importante nas mediações identitárias fabuladas por essas juventudes.

Juventude

Identidades

Projeto e Memória

Enquanto o houve uma consolidação da cultura televisiva, que estreitava a relação entre consumo midiático e práticas juvenis, as condições singulares por que passava o Brasil, no que se convencionou chamar redemocratização, foram sentidas através da abertura política em conjunto com uma crise econômica que perdurou todo o período até meados de 1990. Nos entremeios desse processo as narrativas juvenis emergiram como uma busca por si a partir de uma releitura dos processos culturais localizados no período da ditadura militar.
\end{abstract}




\section{Resumen:}

Ese artículo tiene como propuestaponer de relievelas célebres disputas observadas enlasprácticasjuveniles de 1980 de manera a presentar una mirada sobre la forma como latelevisión se ha convertido enunejemplar importante enlasmediaciones de identidad fabuladas por esas juventudes. Mientrashubo una consolidación de la cultura televisiva, que estrechabalarelación entre consumo mediático y prácticasjuveniles, las condiciones singulares por lo que pasaba Brasil, enlo que se llamaredemocratización, fueran sentidas a través de la apertura política en conjunto con una crisis económica que perduró todo elperiodo hasta los mediados de la década de 1990. Enlosentremedios de tal procesolas narrativas juvenilesemergieron como una búsqueda por sí a partir de una relectura de losprocesosculturales localizados enelperiodo de ladictadura militar.
Palabras clave:

Televisión

Juventud

Identidades

Proyecto

Memoria

\section{Keywords:}

\section{Television}

Youth

Identity

Memory

Project

\section{Abstract:}

The purpose of this article is to assess two memorable disputes acknowledged in the juvenile practices in 1980 in order to present a new perspective on how television became relevant regarding the identity mediations narrated by the young. While there was a consolidation of the television culture - which brought closer together the media consumption and those juvenile practices - there were also unique conditions through which Brazil was going (a process named redemocratization) perceived via the political opening and an economic crisis that lasted for approximately 15 years. Throughout this process, the juvenile narratives arose as an identity search based on a review of the cultural processes related to the military intervention from before. 
Televisão, o futuro será: a consolidação de uma cultura televisa visualizada nas performances midiáticas e juvenis dos anos de 1980

\section{Introdução}

Em 1984, a cantora Bete (Débora Bloch), personagem central do filme Bete Balanço (Lael Rodrigues/1984), se muda de sua cidade natal, Governador Valadares (MG), para tentar carreira artística no Rio de Janeiro. As primeiras cenas mostram uma Bete triste ao descobrir que passou no vestibular para o curso de administração, em meio à alegria de vários jovens que pintam a face dela com batons. Posteriormente, assistimos a personagem deitada na cama do seu namorado, enquanto seu pensamento, narrado em voz over (locução em que um personagem não aparece em cena, mas reconhecemos sua voz), resume o conflito existencial de Bete. Assim, diz ela: "Eu não deveria ter passado nesse maldito vestibular, agora vem o noivado com Deca, a faculdade, ai...".

Nesse mesmo momento, seu desejo se revela para o espectador: a personagem liga a televisão e assiste a um show da banda Barão Vermelho. Enquanto os músicos entoam os seguintes versos, vemos o "sonho" de Bete se projetar na tela quando ela se imagina no lugar da banda continuando a canção:

Há dias que eu planejo impressionar você, mas eu fiquei sem assunto. Vem comigo, no caminho eu explico. Vem comigo vai ser divertido, vem comigo. Eu quero te contaminar de loucura até a febre acabar. Há dias que eu sonho beijos ao luar, em ilhas de fantasia. Há dias com azia o remédio é teu mel, eu sinto tanto frio, no calor do Rio. Já mandei olhares prometendo o céu agora eu quero no grito, vem... (Vem Comigo - Barão Vermelho)
Bete, portanto, toma uma decisão e enquanto assistimos a uma cena em que ela arruma as malas, mais uma vez a locução em voz over, descreve o trecho de uma carta da cantora para seus pais: "Mãe, não adianta eu explicar por que vocês não vão entender nunca, mas eu preciso ir à luta da minha vida, sem ajuda de ninguém...". As imagens que a cantora assiste pela televisão parecem indicar a Bete que caminho ela poderá seguir. Enquanto as cenas são estruturadas em formato videoclipe, aproximando a música juvenil da época ao cinema, o filme constrói um perfil de juventude que vemos surgir na tentativa de Bete se transformar em uma cantora de sucesso.

É nesse sentido que o desejo de Bete desponta em letras de neon as bases de um novo projeto juvenil, baseado no adensamento e entrelaçamentos entre televisão, consumo e juventude. Eis os novos tempos, diz a música temática do filme: "Bete Balanço, meu amor, me avise quando for a hora"3.

Seguindo essa mesma linha, o filme Tropclip (Luiz Fernando Goulart/1985), conta a história de quatro personagens com sonhos diferentes que se reúnem em torno de um projeto comum. Krishna Maria (Tânia Nardini), 17 anos, filha de uma ex-hippie, é dançarina e enquanto aguarda a sua chance de "subir na vida" através do seu sonho; trabalha como vendedora de roupa em uma loja famosa. Herculano Ribeiro (Marcos Frota), 19 anos, é locutor de rádio em Governador Valadares (MG), mesma cidade de Bete e também resolve se mudar para o Rio de Janeiro com o intuito de trabalhar na televisão. Luciana (TicianaStudart), 20 anos, é produtora de teatro e Chico (Carlos Alberto Loffler), 17 anos, é um estudante de informática cujo desejo é criar um jogo eletrônico baseado nos movimentos de dança. Ao se encontrarem, o grupo percebe que os saberes e desejos de cada um podem gerar um 
projeto de vida e com isso, elaboram um videoclipe para um concurso com a intenção de se estruturarem como profissionais de videoclipes.

Acredito que esses dois filmes discutem uma questão similar: como construir um sentimento comum juvenil, relacionando formas de ação a uma perspectiva de sucesso como profissional cujo reconhecimento é a inserção dos jovens no universo midiático. Fazer sucesso, portanto, adquire um novo sentido que a insatisfação de Bete Balanço em relação à aprovação no vestibular e ao casamento deixam margens para entendermos de que lugar essas narrativas estão partindo: uma reflexão em torno do consumo midiático como parte constituinte da formação identitária versus uma tradição moderna (casamento burguês, formação do espírito através do saber acadêmico e estado como provedor do bem-estar social) que parece não mais corresponder aos desejos desses jovens discutidos nos filmes.

A possibilidade de saída da casa paterna e busca de entendimento de si a partir de outras experiências materializadas no consumo midiático abre espaço para uma primeira questão: que tipo de sujeito é esse que essas narrativas nos convidam a perceber? Essa pergunta torna-se evidente quando Betedeixa claro em carta a necessidade de ir à luta da sua vida, pois deflagra um processo de disputa entre um modo de agir de seus pais - jovens nos anos de 1960 - e a da personagem, estabelecendo um contraponto entre visões de mundo nos idos de 1960 e nos de 1980. Em Tropclip essa perspectiva torna-se mais clara ainda no diálogo entre Krishna Maria e sua mãe:

Lúcia (preocupada): Você pensa que este seu sonho, essa sua fantasia, essa sua malandragem você vai conquistar o mundo? Bote os pés no chão, minha filha, no chão.
Krishna (indignada): Você que me diz isso, na minha idade você estava no Nepal curtindo o seu Hare Krishna com o dinheiro do meu avô e agora vem com esse papo? Olha o seu mal é que você foi esmagada pelo mundo e não quer admitir. Será que você não entendeu que a Yoko Ono é uma das maiores fortunas dos Estados Unidos. Dona Lúcia?

Lúcia: Não tem nada a ver com a Yoko Ono, aliás, eu nem gosto dela.

Krishna: Cai na real, Dona Lúcia, olha qualquer dia desse eu vou embora dessa casa e você vai ficar até sem as minhas amigas para fazer seus mapas astrais. Chega de brincar de vítima e vai à luta.

Ir à luta, desse modo, significa assumir a posição de agente central de suas próprias vidas e é por esse motivo, que, nas duas narrativas, os pais não são personagens importantes nos filmes a não ser para evocar uma memória do que esses jovens imaginados não querem ser. Se sairmos do campo cinematográfico e voltarmos para o universo musical, teremos constatações parecidas que podem ser tomadas como indicativos de um tempo novo - que não se sabe muito bem ainda o que significa - mas que possui como ponto de partida alianças entre juventudes, televisão e consumo. Em 1984, a banda Titãs, cantou os seguintes versos:

Babi índio enjoy selva coca-cola. Pode ser que eu vá viajar nesse navio. Não sei,não sei, não sei. Pode ser, pode ser, pode ser. Não sei. Cenas de terror e tensão, fuga na terra, ira no céu. Televisão: o futuro será (Babi Índio/Titãs/1984).

Já em 1986 a banda Engenheiros do Havaii lança seu primeiro disco intitulado "Longe demais das capitais", em que há uma música com os seguintes dizeres: "mas ninguém tem o direito de me 
achar reacionário, não acredito no teu jeito revolucionário"4. É a partir desse jogo relacional entre passado como elemento constituinte do presente que interpreto os jogos memoráveis, esboçados em alguns discursos juvenis do período analisado.

Do mesmo modo o Grupo Legião Urbana, no mesmo ano, canta os seguintes versos: "Desde pequenos nós comemos lixo comercial e industrial, mas agora chegou nossa vez. Vamos cuspir de volta o lixo em cima de vocês. Somos os filhos da revolução, somos burgueses sem religião, somos o futuro da nação, geração coca-cola".

Enquanto a estrofe de Engenheiros do Havaii parece responder à geração juvenil anterior a da banda, apontando que um modelo de conduta, pautado nas ações juvenis da esquerda revolucionária nos idos de 1960, não pode mais ser pensado como projeto identitário nas paisagens oitentistas, a letra da Legião Urbana complexifica um pouco mais esse entendimento de si, ao incluir como referência a consolidação de um modelo de mídia massiva calcado na televisão como parte constituinte também de um projeto de nação nos idos de 1960. Têm-se,inicialmente, dois lugares de entendimento juvenil deflagrado nessas canções: o primeiro baseado no projeto de nação vinculado à chamada esquerda revolucionáriae, dois, o projeto de modernização nacional de direita, apoiado pelos empresários e estado ${ }^{5}$. O resgate desses elementos da memória é usado para justificar uma ação juvenil no presente movida pela raiva, expressa na letra, mas também no tom de voz raivoso de ambos os cantores, como uma espécie de respostaa essas duas projeções identitárias concebidas no regime militar.

É nesse sentido que olhando através dos discursos juvenis de 1980 podemos perceber o diálogo entre duas imagens, referentes a tempos históricos diferenciados, que legitimam a formação de uma nova arquitetura comportamental no período analisado. De um lado, os vestígios de discursos constituídos na geração de 1960. Do outro, uma nova possibilidade de organização social calcada na abertura política e reformulação da democracia. O consumo televisivo, nesse sentido, aparece como resposta ao modelo de modernização autoritária proposto no regime militar, com a estruturação de um parque industrial no país.

Desse modo, Legião Urbana ao cantar a canção Geração coca-cola, assim como a Engenheiros do Havaii, ao dizer que "a juventude é uma banda em uma propaganda de refrigerantes" ${ }^{\prime}$, estão mapeando um contexto histórico, tornando evidente para o seu público as transformações do mesmo a partir de uma série de estruturações advindas do passado, e é dessa maneira também que este apresenta-se como processo de significação nessa geração 80 .

De um lado, a crítica ao projeto revolucionário de esquerda e, de outro, o questionamento diante das consequências da modernização autoritária. Esse artigo tem como proposta por em perspectiva as disputas memoráveis visualizadas nas práticas juvenis de 1980 para apresentar um olhar sobre a maneira como as narrativas televisivas tornaram-se uma instância importante nas mediações identitárias fabuladas por essas juventudes.

Parto do pressuposto que o discurso projetado massivamente e que vincula símbolos de uma cultura de consumo midiático a noção de juventude foi desenvolvido também por uma nova geração televisiva, personificada nos jovens, filhos de uma ditadura militar, que nasceram com o meio televisivo já implantado e começavam a ocupar outro espaço do dizer. 
Essas narrativas juvenis deixam margens para pensarmos sobre a maneira como as aproximações culturais entre juventudes e televisão - visualizadas em práticas midiáticas, tais como cinema, música e programas de televisão - gestou não apenas uma pedagogia de um consumo televisivo no país, como também descortinou os processos contraditórios que envolvia negação/aceitação como esferas de entendimento sobre a televisão ao acionar os refluxos memoráveis dos anos de 1960. Proponho nesse artigo aprofundar um pouco mais dessa arquitetura comportamental, focalizando algumas falas juvenis recorrentemente mediada pelas fábulas televisivas nos anos de 1980.

Esse mecanismo de ação pressupõe não apenas atentar para o processo de modernização nacional, ocorrido nos idos de 1960, por parte do estado autoritário, que, em conjunto com a classe empresarial midiática, promoveu uma extensão de uma incipiente indústria televisiva nos idos de 1950 (período em que o artefato aportou no Brasil) inferindo desde investimento tecnológico, para que a TV pudesse ser assistida nas diferentes regiões que compõem o país; atravessado também a criação de cartas de créditos para que a população pudesse comprar o eletrodoméstico; até transformações racionais das programações televisivas $^{7}$ (Borelli e Ramos: 1989).

Mas, mais precisamente, entender de que maneira os fragmentos memoráveis dos anos de 1960 foram lidos como metáforas de um país que, sob a alcunha de redemocratização nacional, personificou a sensação de novidade: a abertura política passou a ser experimentada como metáforas que envolvia a crença em novas lideranças, novos projetos, novos consumos, novos sujeitos em ação agregando uma política de corpo festiva e eufórica. A televisão, que naquele momento chegava aos trinta anos, ou seja, ainda jovem, as- sumia um papel central na construção de um imaginário do que seria aquele Brasil do por vir.

Assim sendo, quando essas "juventudes 80" proclamaram o direito de se significar via construções televisivas, havia um imaginário vinculado a um projeto de consumo capitalista, remanescente dos anos de chumbo. A análise dos " 80 " poderia ser articulada apenas a essa experiência dos idos de "60", se não fosse o outro lado da moeda, pois enquanto uma esfera política e econômica investia na construção do mercado de bens simbólicos, havia também outro discurso.

Sob os pressupostos de um mundo mais justo e de uma busca por um ideal de Brasil em contraponto a uma modernização capitalista, as ideias de esquerda entraram em disputa com as de direita provocando acirrados debates. Consequentemente, a resposta dessa direita foi gestada violentamente, acarretando em silenciamentos de vozes dissonantes, por meio de prisões, torturas e exílios políticos. É como memória traumática que o período ditatorial apresentou-se como marca das produções televisivas oitentistas (Huyssen: 2001).

Resumindo, os anos 60 , nos idos de 80 , se constituía como uma memória muito recente do passado, que, inclusive, obrigou parte de um grupo intelectual de esquerda a manter-se em silêncio com o recrudescimento da ditadura militar, e essa condição contextual tornava muito difícil o esquecimento. Essa memória estava ali, dentro dos lares brasileiros, na discussão sobre redemocratização, na campanha Diretas Já, eclodindo, brigando para ser explorada, estabelecendo, desse modo, uma tênue relação entre universos privado e público.

Essa memória traumática se complexificouainda mais no cenário nacional 
oitentistatendo em vista que não representou apenas as lembranças de tortura que indicou a vitória das ideias de direita perante as de esquerda. As reorganizações culturais com vistas a uma modernização autoritária nos idos de 1960 foram também experimentadas a partir de uma crise econômica marcada por uma hiperinflação, que em 1985 chegou a um índice inflacionário anual foi de 235 , $11 \%$, duplicando seu valor, em 1987, para $415,83 \%^{8}$, em 1989 chegou a me$\operatorname{dir} 1.764,87 \%{ }^{9}$.

No final do ano de 1980 e início de 1981 , o então ministro do planejamento do governo de João Figueiredo, Delfin Neto, promoveu uma série de pacotes de refreamento do consumo como resposta para uma hiperinflação de $76 \%$. O ministro elaborou um institucional publicitário e disponibilizou nos meios de comunicação, conclamando a população a lutar contra a crise econômica utilizando como ferramenta a poupança. O consumo como marco de um projeto de modernização sessentista, ironicamente, deixava de ser a solução. Diz ele:

De alguns anos pra cá a inflação transformou-se em uma preocupação constante na vida dos brasileiros. Ministros, empresários, cientistas políticos e sociais debatem incessantemente, e os jornais ocupam colunas editoriais com o assunto. Enquanto isso, o Governo Federal tenta unir seus esforços aos esforços da iniciativa privada, com o objetivo de travar por todos os meios a marcha inflacionaria. Dentre as diversas causas apontadas para o fenômeno, uma vem-se destacando de forma cada vez mais preocupante. O consumismo exagerado. O povo brasileiro, tentando defender-se da inflação, compra alem de suas possibilidades, relegando a poupança a uma opção secundária. Bens de todos os tipos, inclusive os supérfluos, são consumi- dos vorazmente, realimentando assim a já abastada taxa inflacionária. Nessa guerra, você - e cada um - é um importante aliado. Consumindo em menor escala, vamos conseguir manter a níveis mais suportáveis os índices da inflação. Se todos estes argumentos não forem suficientes para fazer você pelo menos tentar poupar um pouco mais, talvez você se sensibilize diante de alguns argumentos que, se não tocam fundo no seu bolso, tocam fundo no seu coração. Os recursos que você deposita na poupança são emprestados a quem realmente necessita e usados na construção e no financiamento de casas populares, apartamentos, escolas e hospitais. E, ainda, geram empregos a milhares de brasileiros que dependem direta ou indiretamente da indústria da construção civil. Pense nisso tudo com muito carinho (NETO: A febre do consumo engorda e alimenta a inflação. VEJA: 03/09/1980).

A perspectiva de uma classe média consumidora engendrada no projeto de modernização autoritária que refletiu nos símbolos de uma televisão de mercado esmaeceu, por que todo um imaginário organizado na reestruturação de um campo industrial que aumentou a produção de bens mercantis no país (mesmo essa não atingindo as classes populares) em conjunto com representações televisivas de integração nacional via signos do consumo, projetou no Brasil de 1980 uma imaginação às avessas: era proibido consumir.

Esse processo atravessou toda a década posicionando em um mesmo plano sentimental duas ordenações comportamentais contraditórias. Por um lado, o crescimento de símbolos do consumo via mecanismo midiático como hábitos culturais e, por outro, uma prática formulada pelo estado, também elaborado através de campanhas publicitárias, como mostra 
o institucional acima que tinha como intenção a contenção do consumo.

O institucional de Delfin Neto não foi o único, a cada tentativa de contenção da inflação, discursos similares retroalimentavam esse tipo de representação. Em 28 de fevereiro de 1986, por exemplo, no governo de José Sarney, houve uma campanha intitulada "Sou Fiscal do Sarney" que conclamou toda a população via mecanismos midiáticos a ser vigilante da Tabela da SUNAB ${ }^{10}$. Foi através de um tom emotivo, tentando tocar o coração do consumidor brasileiro, que o presidente discursou para a população ao lançar o cruzado como moeda:

Chegamos à exaustão nos paliativos e nos tratamentos tópicos, e não foi para isso que os inexplicáveis caminhos do destino me fizeram presidente da República [...]. Iniciamos hoje uma guerra de vida ou morte contra a inflação. A decisão está tomada. Agora cumpre executá-la e vencer (VEJA: 05/03/1986).

É nesse sentido que essas experiências gestadas entre consumir e não consumir podem ser pensadas como a formação de um corpo atordoado diante de uma trajetória nacional em retrocesso e, vinculada a noção de um país às avessas. Não é à toa que a revista Veja publica uma matéria, em 1982, sob o título "O sonho acabou: o retrato de uma classe média traída pela economia" (VEJA: 06/01/1982).

Assim, diante desse estado de coisas em ebulição, uma estética autorreflexiva que se constituía como característica pedagógica (já que tornava a televisão o símbolo central das marcas de um consumo midiático nas narrativas identitárias juvenis) aparecia como estratégia narrativa dominante, evidenciando as consequências dos projetos culturais de 1960 nos idos de 1980. O Brasil, nesse sentido, aparecia nas nuances dessas falas como um lugar de cabeça para baixo. Embutida nessas conexões sentimentais, essas juventudes começaram a se perguntar: " $E$ aí, geração 80 ? Como vai você? ${ }^{11 " .}$

\section{O Brasil televisivo no filme Rock Estre- la e em outras canções}

O filme Rock Estrela (Lael Rodrigues: 1985) propõe uma discussão sobre juventude revelada a partir da transformação de um estudante de música erudita, chamado Rock (Diogo Vilela), que passou dez anos aperfeiçoando seus saberes na Argentina cidade de Corrientes - e volta ao Brasil se deparando com um universo completamente diferente do que ele imaginava ser.

Embora o filme não nos mostre cenas do país imaginado por Rock, em algumas falas do personagem passamos a ter uma percepção de que tipo de memória a narrativa seleciona para elaborar um contraponto entre o Brasil que ele redescobre, à medida que ele contempla as paisagens cariocas em sua volta e se assusta - "com letras de neon e tudo"12; com a imagem de país que ele deixou ao embarcar para a Argentina. As dúvidas do personagem tornam-se o fio condutor para discutir tempo histórico, projeto juvenil e televisivo 80.

Esse novo Brasil que vemos é uma metáfora de uma vitrine televisiva, pois através de cores brilhantes, luz neon, exibição de equipamentos de filmagem e encenações do aparelho no cotidiano dos personagens personificam as relações entre as narrativas televisivas e a busca por identidade do personagem Rock. Nas superfícies dessa discussão há um cenário controverso, o passado rememorado é visto nas imersões de um presente em crise e é essa lembrança que legitima narrativamente a necessidade de um novo projeto identitário. 
Em tom cômico, a história alinha através das incertezas do personagem, um discurso duplo que se apropria de uma estética nosense (personagens olham para a câmera, televisão interage com espectador, cenas paralelas construídas em espaços temporais diferentes se juntam em um mesmo espaço cênico) como artefatos estéticos para que um passado memorável seja visto em prospectiva e, desse modo, legitime a escolha pela "televisão" como resposta dessa busca identitária no final do filme.

A televisão torna-se a saída, porém não sem contradições; fato que demarca que o desejo em ser TV proclamado por essas falas juvenis destronam uma afiliação comportamental vista como alienada e passiva se pensarmos esse debate no diálogo entre imagens de massa e o conceito de indústria cultural, proclamado por Adorno e Horkheimer (1991), no entendimento sobre a massa como conceito. Paraesses autores, o englobamento da cultura pelo mercado enforca a possibilidade de construção de uma visão crítica de mundo, já que a categoria política para ambos é separada da perspectiva de mercado.

Essa resposta pelo campo televisivo se estabelece a partir de uma seleção memorável que se articula no filme vinculadaà crise das utopias das duas principais práticas identitárias contidas nos anos de 1960 (projeto de direita versus de esquerda). Essas memórias deixam marcas para se pensar que novo tipo de projeto ancora essas identidades juvenis. Como sugere Velho (2006), atentar para essa questão implica visualizar um contexto histórico de adensamento do individualismo em função de uma maior possibilidade de papéis sociais que o sujeito é conclamando a representar.

Nessa perspectiva, o projeto é uma ferramenta reflexiva de organização identitária que se articula a outros sujeitos e/ou grupos de indivíduos. É um modo de comunicação que relaciona performances a hábitos, vínculos, sensações e projeções do futuro no presente. Entender a formulação de um projeto em sociedades complexas significa adequar características identitárias socialmente conferidas, tais como classe social, gênero, faixas etárias, entre outras, a um "campo de possibilidades" de ação, o que significa dizer, nas palavras do autor, o reconhecimento de limites e "constrangimentos de todos os tipos" (VELHO, 1994: 104).

Assim, na formação das identidades coletivas e individuais, projeto e memória, "são amarras fundamentais", pois relacionam "visões retrospectivas e prospectivas" como lugar de ancoragem que desenham nos sujeitos "motivações" e ações justificadas "dentro de uma conjuntura de vida" que contornam os caminhos por meio dos quais os indivíduos constroem suas biografias (IDEM: 101). Mas que prospectiva essas memórias ofereciam para essas juventudes?

Pensar o contexto dos anos 80 a partir do que se tornou essas memórias no presente implica lidar com as marcas paradoxais desses enquadramentos, principalmente no que se refere à memória traumática, pois, por trás de projetos nacionais de direita e de esquerda, havia uma sensação esvaziamento de projetos, em virtude do recrudescimento da ditadura militar, gestando um olhar melancólico sobre o passado (Pollak: 1989; Huyssen: 2001).

Assim, ora essa memória era amada, pois ainda que dolorida, representava um lugar de ancoragem, crença e refúgio possível, em função de um futuro também imaginado nos esteios de uma crise econômica; ora ela era odiada, tendo em vista que a noção de trauma sobrevalorizava o sentimento de descrença em relação a esse futuro do 
presente; ora essas duas imaginações andavam de mãos dadas.

\section{É nesse sentido que o presente} vivido gestava uma sensação de colapso, pois mesmo nos espaços de consumo televisivo em que novos estilos de vida apresentavam-se amarrados a uma perspectiva comemorativa e consumista (deflagrando uma necessidade do esquecimento por parte do estado e do mercado das gestões traumáticas), a perda das utopias sessentistas em conjunção com a crise econômica que o país atravessava, tornava-se um indicador de falta de perspectiva, fato que acarretava na busca por um novo projeto esmaecido de certezas originadas na maneira como as trajetórias da modernização autoritária foi constituída no Brasil.

Assim, a autorreflexividade apresenta-se como um modo central de lidar com os diálogos entre passado/presente e futuro/presente. É desse modo que, pensando nas contingências históricas do tempo em que analiso, concordo com VeIho quando este diz que:

De forma aparentemente paradoxal em uma sociedade complexa e heterogênea, a multiplicidade de motivações e a própria fragmentação sociocultural ao mesmo tempo em que produzem quase que uma necessidade de projetos, trazem a possibilidade da contradição e do conflito (VELHO, 1994, p. 104).

É, portanto, com esses desdobramentos do passado e do futuro no presente, que essas juventudes 80 tiveram que negociar ao construírem suas identidades vinculadas ao contexto massivo de uma cultura televisiva em processos de consolidação. Assim, retomando a análise do filme, na primeira sequência, assistimos a chegada de Rock (Diogo Vilela) no Aeroporto Internacional do Rio de Janeiro (Ga- leão) enquanto ouvimos a música tema e de nome homônimo, entoada por Léo Jaime, que também atua na película como o primo roqueiro Tavinho, que além hospedar o personagem principal tem a função de mostrar para ele uma nova imagem de Brasil. Numa proposta questionadora e autorreflexiva, diz um pedaço da letra:

Quem sou eu? E quem é você? Nessa história eu não sei dizer. Mas eu acredito que ninguém tenha vindo pro mundo a passeio... De onde se vem? Prá onde se vai? Só importa saber prá quê e pra quem, Pois o destino transforma num dia um menino em herói de TV (Rock Estrela - Leo Jaime)

Em seguida, assistimos a entrada de Rock (Diogo Vilela) na casa do primo, trajando paletó, gravata em tons de cinzas e um cachecol enrolado no pescoço. Ao tocar a campainha, ele se depara com uma festa com músicas estilo BRock ${ }^{13}$, luzes de neon e roupas coloridas. Uma moça (não identificada) abre a porta e se assusta, pois há um claro contraponto entre o figurino utilizado pelos personagens da casa e Rock - a personagem acha que Rock é um policial.

Assistimos nessa visão inicial da moça, dois mundos diferentes compartiIhando o mesmo ambiente que se intensifica na carta em que Rock (já trancado no seu novo quarto) escreve para a namorada Graziela (Malu Mader) deixada na Argentina. Nesse início, já visualizamos a discussão proposta pela narrativa. Em trechos do texto, ouvimos sua voz: "eu fugi, fugi sim. Fugi de tudo e de todos. É, a minha cabeça não tava legal. Eu quero uma mudança, eu quero mudar minha vida. Eu sei que eu vou encontrar algo estranho. Eu sei. Se bem que eu temo pela minha razão nesse país louco".

Se pensarmos na letra da canção da banda Legião Urbana Que país é 
esse?,quando o cantor, diz em tom raivoso: "Terceiro mundo, se foi. Piada no exterior, mas o Brasil vai ficar rico. Vamos faturar um milhão. Quando vendermos todas as almas dos nossos índios num leilão. Que país é esse?". Podemos entender uma perspectiva de incredulidade performada nas ações de Rock. O filme discute um país que ele não possui nenhum referencial do presente - sua relação com o Brasil é o passado imaginado, no mesmo momento em que seu corpo deflagra as consequências desse passado no presente acionado pelo filme. É, portanto, uma busca de si emaranhada nas configurações de um corpo juvenil televiso a resposta que vemos surgir na narrativa.

É essa busca por si, visualizada em questionamentos e o uso do pronome eu, em conjunto com práticas visuais caracterizadas pelo desvelamento dos processos de produção televisivos que nomeio como autorreflexividade pedagógica. É através dessa estética que, a meu ver tornou-se central nas narrativas midiáticas para e/ou produzidas pelas juventudes, uma nova arquitetura comportamental juvenil pode ser pensada como um imaginário do período analisado.

Em um momento da história, há um diálogo entre Rock e seu primo. Tavinho (Léo Jaime) convida o primeiro para ir a uma danceteria de rock (Help) e eis que o protagonista responde: "eu Beethoven, Villa-Lobos, detestamos esse tal de rock, sabia? É uma música sem passado". Em seguida, Tavinho responde: "É? E quem precisa de passado, xará? Quem vive de passado é bandido, morô?". Em seguida vemos Rock tocando a música Bachianas $n$. 5 (Villa-Lobos) em um violino para uma plateia de personagens velhos que estão quase dormindo. Quando o concerto finaliza, o personagem olha para a câmera e diz: "passei, or not passei. That is the question", parodiando a frase dita por Hamlet.
Acredito, anteriormente quando da análise do filme Bete Balanço, que há nesse trecho, uma disputa de significação entre essas juventudes pelo que eles não querem mais ser lembrados e, apesar de nesse filme o passado corporificado na imagem de Rock referenciar a música erudita, como uma perspectiva de imaginário nacional "puro" anterior aos anos 60, a narrativa posteriormente encena um alinhamento entre essa personificação e a memória de tortura.

Assim, em uma montagem paralela vemos a banda de Tavinho chegar a um estúdio musical enquanto Rock toca um saxofone. Assistimos ao diálogo entre Tavinho e o saxofonista oficial da banda (Tim Rescala) que, ao ouvir o som que Rock produz, assusta-se e fala para o primeiro:

\section{Saxofonista (exageradamente ner- voso e agressivo): Pô Tavinho, tem coisa aí cara. Que som estranho é esse?}

Tavinho (relaxado): Eu to gostando.

Saxofonista: Porra cara! Será que você não sente? Esse som é negócio de ditadura, tortura, Cia. Porra, cara!

Rock, portanto, evoca outra memória. Essa lembrança, do sanfonista, remete a um tipo de juventude 60 de direita que, na fala do saxofonista, dá a entender que apoiou o regime militar, e, por esse motivo, o medo é deflagrado na interpretação que ele faz do protagonista. Há que se discutir, porém, que mesmo naquilo que nomeamos de juventude 60 de direita - vinculada aos sonhos de consumo e da competitividade que indicava uma crença no capitalismo de mercado - a forma como a violência do estado ditatorial foi experimentada apresenta-se como silenciamento de um projeto, um lugar no mundo e, portanto, um lado a que se apoiar como característica identitária. Esse resíduo também faz parte das imagens juvenis 80 , como sugere trechos 
da canção, do grupo Camisa de Vênus, Simca Chambord (1986):

Um dia meu pai chegou em casa, nos idos de 63 e da porta ele gritou orguIhoso, agora chegou a nossa vez! Eu vou ser o maior, comprei um Simca Chambord. E no caminho da escola eu ia tão contente, pois não tinha nenhum carro que fosse na minha frente. Nem Gordini nem Ford, o bom era o Simca Chambord. O presidente João Goulart, um dia falou na TV que a gente ia ter muita grana para fazer o que bem entender, eu vi um futuro melhor, no painel do meu Simca Chambord. Mas eis que de repente, foi dado um alerta. Ninguém saía de casa e as ruas ficaram desertas. Eu me senti tão só, dentro do Simca Chambord. Tudo isso aconteceu há mais de vinte anos, vieram jipes e tanques que mudaram os nossos planos. Eles fizeram pior, acabaram com o Simca Chambord.

Em torno de uma memória recente da violência sessentista - tanto na juventude de direita, quanto da de esquerda, o filme parece indicar que não restou crenças a serem seguidas. A crise de identidade dessa geração incorpora essa sensação de esvaziamento. É dessa maneira também que a lembrança apresenta-se para o protagonista como um peso identitário. É a partir desse passado no presente que Rock parodicamente ("passei, or not passei") conclama o espectador a entender o que está por trás de um processo de consolidação da cultura televisiva. Essa é a questão, diz ele, deflagrando as tensões marcadas nos diálogos entre dois pensamentos de nação, vinculados a uma tradição moderna e, por outro lado, na emergência de uma prática de consumo adensado como lugar de pertencimento. São essas disputas que formulam essa arquitetura comportamental juvenil e televisiva.
É nesse sentido que em um mesmo sujeito encontramos frases como: "eu prefiro Toddy ao tédio"14, descortinando as imersões dessas juventudes nos cenários de consumo como lugar de fabricação identitária, e "a burguesia fede, a burguesia quer ficar rica. Enquanto houver burguesia, não vai haver poesia", como crítica ao cenário musical de mercado inscrita na palavra burguesia ${ }^{15}$.

As performances de Cazuza escorregando entre essas duas imaginações é um exemplo de como esses jovens tiveram que negociar com as consequências do seu passado em que se enxergar como indivíduo remetia a um complexo feixe de práticas culturais que não podiam mais ser interpretadas de forma dicotômica: ser direita ou ser esquerda, o cenário era outro e as narrativas televisivas ou sobre televisão colocavam esses dois planos de interpretação em diálogo.

São essas complexificações que recolocam a questão da identidade como uma das instâncias centrais na agenda cultural brasileira dos anos de 1980. Esta é mapeada em uma disputa por definição de si que, na verdade, fabula uma memória social de um tempo histórico, no sentido que Maurice Halbwachs (1990) concebe o termo. Assim, quando o cantor Cazuza lança a música Ideologia (1988), esses cenários imbricados tornam-se evidentes em dois níveis.

Ao escutarmos a música temos uma dimensão concreta sobre o diálogo do cantor com um vestígio do passado, pois ao tentar se definir, definindo, com isso seu tempo, ele volta-se para um projeto identitário (anos 60) que no seu presente aparece como ausente (mas é indiscutível que ele torna-se presentificado em suas falas). Claramente, o cantor está discutindo com uma ideia de ser jovem enquadrada pela perspectiva da crítica cultural de esquerda. Diz ele: 
Meu partido é um coração partido e as ilusões estão todas perdidas. Os meus sonhos foram todos vendidos,tão barato que eu nem acredito que aquele garoto que ia mudar o mundo frequenta agora as festas do Grand Monde. Meus heróis morreram de overdose, meus inimigos estão no poder. Ideologia, eu quero uma pra viver. $\mathrm{O}$ meu prazer agora é risco de vida, meu sex and drugs não tem nenhum rock ' $n$ ' roll. Eu vou pagar a conta do analista pra nunca mais ter que saber quem eu sou, pois aquele garoto que ia mudar o mundo agora assiste a tudo em cima do muro. Ideologia, eu quero uma pra viver (Ideologia - Cazuza).

Ao estabelecer uma necessidade de outros parâmetros identitários em função do que se tornou, nos idos de 1980, a imagem de 1960 a que ele se afilia, Cazuza, aponta o consumo intensificado como justificativa central no esfacelamento dos seus "sonhos vendidos, tão barato" que ele nem acredita; mudar o mundo, dessa maneira, tornou-se impossível. Sua fala, através do olhar para essa letra, indica, portanto, que o autor ainda se percebe como sujeito a partir de uma dicotomia entre ser parte constituinte de um imaginário de nação dividido nos discursos de direita e de esquerda: ou se é isso, ou se é aquilo, mesmo que aquilo esteja, de certo modo, esmaecido e o cantor queira esquecer quem ele é.

Por outro lado, ao assistirmos a música na configuração do videoclipe ${ }^{16}$, outra imagem identitária aparece nas performances audiovisuais do cantor muito mais complexa, posto que à medida que suas frases são entoadas, vemos um cantor dançando, criando faces que remetem a ideia de incredulidade diante do que ele percebe como mundo no seu tempo, no mesmo momento em que o cantor ri delas. Em algumas cenas, ele aparece trajando um chapéu característico do parque de di- versões americano Disneyworld, cujo formato é desenhado em função das orelhas do personagem Mikey Mouse - emblema do parque.

No início do videoclipe assistimos a uma imagem se formar na tela com a palavra ideologia que se monta cena a cena, com memórias visuais de um tempo histórico com o qual a canção dialoga (o conjunto dessa imagem forma a capa do disco de nome homônimo). Desse modo, a letra É, é formada com a estrela vermeIha em junção com os desenhos da foice e do martelo, signo do partido comunista; o primeiro $\underline{0}$, pela Cruz de Nero, ou em linguagem comum - pé de galinha (uma cruz de cabeça pra baixo, dentro de um círculo, com os braços caídos), emblema das práticas hippies inscritas na contracultura. O segundo $\underline{O}$ é fabulado pela estrela de Davi, sendo que, no centro desta, forma-se a imagem da suástica, memória do Holocausto e da segunda guerra mundial; e, por fim, a letra $\underline{A}$, traduzida pelo símbolo do movimento Anarquista.

Na sequencia posterior, o clipe dá a ver uma soma de imagens em plano detalhe e editadas por cortes rápidos de pés com diferentes tipos de sapatos: um coturno, sapato social, sandálias de couro, tênis da marca All Star, entre outros, que têm como função indicar uma releitura desse passado nas condições culturais do período histórico em que a música se constitui. Não é à toa a presença do tênis All Star como estilo de vida juvenil, referência que eleva o consumo como paisagem a ser discutida. Entre os símbolos do consumo e os resíduos, encontra-se uma performance do cantor em tons de deboche que modifica a nossa percepção da canção. Entre outras representações, o cantor dança, faz caras e bocas parodiando sua própria letra. Em duas sequências do vídeo, essa nova tonalidade da música torna-se mais evidente. 
A primeira delas refere-se aos momentos em que frases como "agora assiste a tudo", ou que remetem ao universo midiático são ditas pelo cantor. Vemos Cazuza em um estúdio de vídeo, dramatizando a experiência de assistir um filme e/ou um programa televisivo. Ele aparece de costas (contra-plano) sentado em um sofá assistindo TV, enquanto as imagens de novelas e filmes em junção aparecem como foco principal da cena. Quando a câmera volta-se para o rosto do cantor em primeiro plano, assistimo-lo brincando com um negativo fílmico; em alguns momentos ele morde, em outros ele utiliza o material para fechar seus olhos e, assim, o aparelho televisivo torna-se um personagem vivo, que dialoga com o cantor, como referência às novas experimentações culturais dessas juventudes diante do universo midiático.

A segunda encena as frases "e aquele garoto que ia mudar o mundo, agora assiste a tudo em cima do muro" na segunda parte da canção. Vemos Cazuza sentado em uma pilha de livros (o muro) com um capelo na cabeça (chapéu utilizado em formaturas escolares). Em um determinado momento, ele chuta esses livros e, em seguida, o vemos rasgar com o corpo um papel com o símbolo do personagem em quadrinhos Batman (desenho de um morcego). Essa última imagem se repete com o cantor rasgando alguns símbolos que formaram a palavra ideologia no início do seu clipe.

A partir dessas referências, temos um pensamento sobre o universo massivo em evidência, só que ao invés de um posicionamento político de oposição a esse mundo, no videoclipe, o cantor se diverte, passeia pelos cenários, brinca com suas mãos em frente à televisão, como se estivesse criando novos enquadramentos das imagens que são processadas pelo meio. É nesse sentido que certa postura dicotômica que poderíamos perceber como ex- pressão do cantor, ao apenas ler a letra de sua música, perde sentido, e revela reconfigurações da memória em um cenário social marcado pela vitória da direita, mas em processos de negociação mais complexo entre essas duas visões de mundo sessentista. Esse vídeo parece nos dizer que o projeto identitário juvenil de 1980 parece ser um mergulho dialógico, em que os posicionamentos políticos do cantor abrem-se a outras leituras de validação de uma cultura televisiva.

É com esse mesmo tom que enxergo as imagens de arquivo da banda Titãs, no filme $A$ vida até parece uma festa (Banco Mello e Oscar Rodrigues Alves/2008), quando assistimos Marcelo Frommer, integrante do conjunto, falando sobre a música "Televisão"em um programa televisivo não indicado no filme. Diz ele: "A música televisão fala a televisão me deixou burro, muito burro demais, agora todas que eu penso me parecem iguais, a letra diz isso, mas a gente sempre curtiu televisão, a gente quis falar sobre televisão que é uma coisa importante pra gente".

Em seguida, assistimos cenas dos integrantes entoando a canção no Cassino do Chacrinha (TV Globo: 1982), brincando com um aparelho televisivo enquanto cantam. Em um determinado momento, Arnaldo Antunes se abraça ao aparelho deitado no chão do programa. Essas contradições margeiam o discurso desses jovens artistas e precisam ser revistas à luz das suas performances midiáticas se quisermos perceber o tipo de negociação que se estabeleceu entre juventude e mídia nas formulações identitárias.

A televisão é um objeto de análise crítica nessas duas canções, pois se torna referência de mundo importante. Aparece, nesse sentido, como uma releitura do universo massivo nos idos de 1980. É preciso lembrar que essa geração nasceu com o aparelho no centro de suas salas de estar, 
sendo, portanto, acostumados a ver TV desde pequenos. Assim, em um contexto em que o consumo midiático se expande e a formação de uma cultura televisiva aparece como marcas desse processo, nada mais justo do que tornar a mídia um personagem discursivo das suas próprias especulações identitárias.

Por outro lado, de que lugar essas juventudes falavam senão no seio da própria burguesia? É preciso deixar claro que nos idos de 1980 a disputa por significação nos setores midiáticos ficou centrada entre visões de mundo de classes médias de gerações diferentes. O popular, ou uma apropriação do popular sentida no BRock (aqui, estendo a sigla não só para o movimento musical, mas para práticas midiáticas inscritas no cinema, nos livros e na televisão), tornou-se uma forma de espeIhamento que mais uma vez permaneceu circunscrita a uma mesma classe social como lugar de saber. Foi através dos conflitos entre gerações de classes médias diferentes que uma noção de cultura televisiva se constituiu.

Retomando o filme, Rock, afinal, sem saber como lidar com todos esses questionamentos em torno de si, resolve voltar para a Argentina e encontrar com a namorada. Eis que de repente, Corrientes e Graziela (Malu Mader) aparecem completamente diferentes para ele e para nós, espectadores. Nas primeiras imagens do filme, enquanto escreve a carta para a namorada, vemos uma Graziela, em tom romântico ${ }^{17}$, que indica para 0 espectador um sentimento de inocência surgindo na tela: virgem, bondosa que ajuda os velhinhos a atravessarem a rua, de vestido godê, como mangas bufão (fofas e altas) e um laço na cabeça em tom cor de rosa claro.

Já nessa volta, o mundo festivo de roupas coloridas e rock androll, desponta como paisagem nas ruas e nas vestimen- tas de Graziela. Eis que um diálogo entre os dois, após uma cena de sexo, indica o início da transformação de Rock:

Rock: Saquei viu? É a revolução.

Graziela: Que revolução que nada Rock: É a revolução, claro que é! Olha, eu nunca tinha visto a Corrientes com esses olhos, nunca vi nada. Nunca te beijei, nunca te amei. Eu te amava como se você fosse, assim, uma deusa intocável. De repente eu percebi que você era de carne e osso. Graziela: E foi bom?

Rock: Não sei,to meio confuso. É mais de qualquer forma, preciso mudar, né?

Graziela: As coisas vão mudando, vai dar um giro por aí. Vai ver o mundo como ele é, e não como a gente sonhou que ele fosse, vai? Vai ver um show e se divertir.

O diálogo reflete justamente uma quebra de uma visão romântica de mundo, que se pendermos para o lado da direita, ou para a esquerda como memóriasexperimentadas nos idos de 1980 encontraremos - guardadas as devidas proporções - sensações parecidas por que estas refletem a ideia de uma crença no futuro que não se apresenta como perspectiva para as juventudes 80 . É nesse sentido que a descrença emoldura o riso e o divertimento festivo projetado nos espetáculos televisivos que esta geração foi também agente constituinte de suas fabulações.

É nesse mundo imaginário televisivo que a resposta aparece, mas sob que experiências? É esse questionamento que, a meu ver, aparece como operação de sentido que torna a lembrança uma reflexão de crise muito mais complexa em torno de uma cultura da memória, pois essa ancoragem no passado como tentativa de agarramento a uma perspectiva de continuidade também sugere uma 
necessidade de apagamento daquilo que pretende ser lembrado (Huyssen: 2001). Ser televisão para essas juventudes, portanto, significava o que? A meu ver, essa pergunta se constituiu como questão embutida nas narrativas autorreflexivas encontradas nessa geração.

Por esse motivo, não querer ser passado, nos exemplos inscritos nessas práticas juvenis 80 , refere-se a retomadas desse passado recente que ora elaboram uma perspectiva de espaço de pertencimento, ora apresentam-se como a inexistência de um lugar possível. Um discurso duplo que reflete as angústias sentimentais vinculadas ao contexto de redemocratização como busca de si.

É dessa maneira que no final do filme vemos um Rock totalmente modificado, com jaquetas de couro, brincos na orelha, óculos escuros, tocando com Tavinho que mais uma vez performa a canção temática do filme. $O$ tom das imagens encenadas é marcado por um excesso de luzes coloridas que refletem a transformação do protagonista em um "herói de TV", como sugere a letra.

Rock Estrela, desse modo, é um enquadramento memorável de um comportamento juvenil daquele presente. A festa, o brilho, as olhadas para a câmera nos convidam a enxergar os entrelaçamentos entre cultura jovem e cultura televisiva. $E$ como sugere Léo Jaime em fala à seção "Gente", da Veja (21/07/1985): "Achei o filme ótimo. Ele acaba com o mito de que todo roqueiro é doidão, todo atleta, burro e todo jovem, militante comunista", posto que há outro tipo de juventude encenada.

Acredito que essas falas reverberam trajetórias de uma revisão da cultura massiva menos dicotômica, mas não necessariamente menos crítica.Nos anos de 1980, as narrativas juvenis foram atravessadas por investimentos políticos e econômicos que corroboraram para o assentamento de uma cultura televisiva no país. O governo brasileiro, mais precisamente no ano de 1981, aprovou a fabricação de videocassetes caseiros, na Zona Franca de Manaus pela empresa Sharp $^{18}$, propagandas com o surgimento de câmeras de vídeo portáteis apareceram nos circuitos midiáticos ${ }^{19}$, fortalecendo a reorganização da vida social como práticas memoráveis, vinculadas cada vez mais aos recursos tecnológicos midiáticos ${ }^{20}$.

Criou-se, desse modo, um cenário cultural cuja plataforma central era a televisão, tendo em vista o investimento governamental e mercadológico gestado nos idos de 1960 e aprofundado nos de 1980 ao redor desse tipo de mídia. É no conjunto dessas práticas que a televisão se consolidou como um campo cultural nos idos de 1980 e espraiou-se como imaginário nacional.

Acredito que entender as imagens do consumo televisivo através das narrativas dessas juventudes 80 possa ajudar a empreender um olhar mais complexo as trajetórias culturais televisivas, pois nas maneiras de consumi-la culturalmente evidenciadas nessas projeções comportamentais, há que se pensar em como se dão as disputas por significação que envolvem um feixe de relações entre diferentes campos sociais (BOURDIEU: 1983).

Desejar ser TV, portanto, é lugar de pertencimento que pressupõe políticas de visualidades que compreendem as distinções promovidas nas maneiras como os comportamentos passam a ser qualificado e, portanto, constituem-se como lugar identitário. São inquietações vinculadas a maneira como esse desejo emana visões de mundo que justificam a correlação entre televisão e cultura, pois nos ensinamentos encantados dos reinos 
televisivos, arquitetou-se todo um modo de vida vinculado a construção de um consumo emocional televisivo, mas não necessariamente silenciado de questionamentos e interjeições.

\section{Bibliografia}

ADORNO, T. W. e HORKHEIMER, M. Dialética do Esclarecimento: fragmentos filosóficos. Rio de Janeiro: Jorge Zahar, 1991.

BORELLI, Silvia e RAMOS, José Mario Ortiz. A telenovela diária. In: Telenovela: história e produção. São Paulo: Brasiliense, 1989.

BOURDIEU, Pierre. A metamorfose dos gostos. In: Questões de Sociologia. Rio de Janeiro: Marco Zero, 1983.

Gostos de Classe e estilos de vida. In: Pierre Bourdieu: Sociologia. ORTIZ, Renato (org.). São Paulo: Ática, 1983b.

CAMINHA, Marina. O corpo juvenil televisivo: diálogos entre televisão, juventudes e consumo nas ondas de Armação llimitada e TV Pirata. Tese de Doutorado. Universidade Federal Fluminense/ UFF, 2012.

SITE CAZUZA. Disponível em: http://www.cazuza. com.brl, acesso em 2009-2012.

FOLHA DE SÃO PAULO. Ano acaba com superinflação de 1.764\%: 29/12/1989.

HOLLANDA, Heloísa Buarque de. Impressões de viagem: CPC, vanguarda e desbunde - 1960/70. Rio de Janeiro: Aeroplano, 2004.

HUYSSEN, Andreas. Seduzidos pela memória. Rio de Janeiro: Aeroplano, 2001.

ORTIZ, Renato. A moderna tradição brasileira. São Paulo: Brasiliense, 2001.

POLLAK, Michael. Memória, esquecimento, silêncio. In: Estudos Históricos. Rio de Janeiro, vol. 2, n. 3, 1989.

Memória e Identidade Social. In:

Estudos Históricos. Rio de Janeiro, vol. 5, n. 10, 1992.
RIDENTI, Marcelo. Em busca do povo brasileiro: artistas da revolução, do CPC à era da TV. Rio de Janeiro: Record, 2000.

SCHWARZ, Roberto. Cultura e política. São Paulo: Paz e Terra, 2001.

Nacional por subtração. In: Que horas são?. São Paulo: Cia. Das Letras, 2002. VEJA. Gato por lebre: confecções falsificam etiquetas famosas. 03/09/1980.

Made in Manaus: governo autoriza a Sharp a fabricar VHS. 26/08/1981.

O sonho acabou: o retrato de uma classe média traída pela economia: 06/01/1982.

Seção Gente: Nota sobre o filme Rock Estrela, com comentário de Léo Jaime. 21/08/1985.

Começa a era do cruzado: 05/06/1986.

VELHO, Gilberto. Projeto, emoção e orientação. In: Individualismo e cultura. Rio de Janeiro: Zahar, 1981.

Memória, identidade e projeto. In: Projeto e metamorfose: antropologia das sociedades complexas. Rio de Janeiro: Zahar, 1994.

1 Essa discussão foi apresentada no Colóquio Brasil-Argentina, na Universidade Federal do Rio de Janeiro (UFRJ), em 2013. É parte constituinte de minha tese de doutorado em que uma ampla pesquisa de programas televisivos elaborados pela e para as juventudes foram transmitidos pelas emissoras nacionais durante a década, tem-se uma média de 40 a 50 programas criados. No capítulo três da tese, procurei avaliar as reflexões sobre televisão em outras produções midiáticas visualizados no cinema, nas músicas juvenis, mas também nas matérias de jornais e revistas, tais como VEJA, ISTO É, EXAME, FOLHA DE SÃO PAULO e JORNAL DO BRASIL, mostrando como se desenvolveu o debate sobre a televisão a partir das reflexões inscritas nas falas juvenis que envolvia uma rememoração das práticas culturais dos anos de 1960 como costuraimportante no processo de consolidação de uma cultura televisa, termo esse que implica não só um aumento de audiência, mas principalmente as inter-relações entre os espectadores e os símbolos do consumo televisivo como projeção de corpo e, portanto, gestões culturais em disputa. Cf. CAMINHA, Marina: 2012. 
2 Pós-doutoranda do Programa de Pós Graduação em Comunicação e Consumo pela Escola Superior de Propaganda e Marketing (ESPM-SP). Doutora em comunicação social, pela Universidade Federal Fluminense. Email: marinacaminha@hotmail.com.

3 Música Bete Balanço, da banda Barão Vermelho, lançado em um compacto intitulado Tema do filme Bete Balanço, em 1984.

4 O título da música é Fé Nenhuma.

5 No primeiro capítulo da minha tese, discuti os trânsitos entre as identidades juvenis vinculadas aos projetos de direita e esquerda no Brasil de 1960, relatando, inclusive, as estratégias de negociação entre esses dois lugares nos processos de formação inicial das mídias televisivas. Para aprofundar essa discussão, ver também Ridenti (2000), Schwarz (2001, 2002), Hollanda (2004) e Ortiz (2001).

6 A frase citada faz parte da música Terra de Gigantes, do disco A revolta dos Dândis, lançado em 1987.

7 Como sugerem Borelli e Ramos, em 1965, 333\% da população possuíam aparelhos televisivos. Adiante, novas emissoras foram aparecendo nos trânsitos gestados a partir da formação de um cenário de bens simbólicos nos idos de 1960, tais como TV Globo (1965), TV Bandeirantes (1967), TVS (1976), e TV Manchete (1981), além das já existentes, TV Record (1953), TV Excelsior (1959) e TV Tupi (1950). Cf.Borelli e Ramos: 1989.

8 Cf. Banco de dados do jornal Folha de São Paulo. In: http://almanaque.folha.uol.com.br/dinheiro80.htm, acesso em 20/06/2012.

\section{Cf. FOLHA DE SÃO PAULO: 29/12/1989.}

10 Em 28 de fevereiro de 1986, Sarney lançou o Plano Cruzado. O projeto constituiu-se por uma tentativa de correção monetária, abortando o cruzeiro (moeda em circulação na época), e apresentando uma moeda nacional nova. Tal perspectiva inferiu em uma política de congelamento do preço que passou a ser determinada pelo governo federal com a criação da tabela da SUNAB.

11 Título de uma exposição de artes plásticas apresentada no Parque Lage (Rio de janeiro), em 1984. Em 2004, essa mesma exposição foi reapresentada pelo centro Cultural Banco do Brasil em três capitais nacionais (Rio de Janeiro, Brasília e Recife), com o título: "onde está você, geração 80 ?".

12 Frase da canção Vai à luta, composta por Cazuza e Rogerio Meanda: "Eu li o teu nome num cartaz, com letras de neon e tudo. Ano passado diriam que eu tava maluco. O pessoal gosta de escrachar. De ver a gente por baixo, pra depois aconselhar. Dizer o que é certo e errado. Eu te avisei: Vai à luta, marca teu ponto na justa. O resto deixa pra lá...".
13 Sigla criada por Nelson Motta e difundida pelo jornalista Artur Dapieve como um modo de identificação dos diferentes grupos musicais juvenis vinculados ao ritmo rock e suas variações. Cf. Dapieve, 1995.

14 Frase assinada por Cazuza e estampada nas camisas vendidas pela Sociedade viva Cazuza. Cf. www. sociedadevivacazuza.org.br, acesso em 10/02/2009.

\section{Canção intitulada Burguesia.}

16 Para assistir ao videoclipe, basta acessar o site WWW.youtube.com, no endereço http://www.youtube. com/watch?v=AuZ6ubVXOoo, acesso em 04/03/2012

17 Obviamente que o filme é cômico, a intenção no exagero da roupa é para marcar o riso, mas também para entendermos os contrapontos discutidos no filme.

\section{Cf. VEJA: 26/08/1981.}

19 Cf. Propaganda da primeira câmera de vídeo portátil, Betamovie (Sony). VEJA: 03/10/1984. Ver também série de campanhas da marca Sharp na década de 1980, elaborada pelo estúdio Start Desenhos Animados. Entre elas constam as animações, com influências surrealistas, Imagens e cores da nossa terra (1976), sobre o lançamento da TV em cores; Pássaros (1980) - a campanha ampliava a noção de imagem, agregando valor simbólico ao videocassete e câmeras filmadoras portáteis. Cf. Nova era. http:// www.youtube.com/watch?v=eMw9iAm95Lo, acesso em 14/08/2011. www.startanima.com.br, acesso em 28/03/2012.

20 A imagem eletrônica, nesse sentido, apresenta-se como uma ferramenta ordenadora da vida cotidiana, tanto de maneira oficial, quanto em vestígios subterrâneos (gravações caseiras), no dizer de Pollak, conformando um estreitamento entre juventude e universo televisivo. 